\section{THE VACATIONS OF A NATURALIST.}

THOSE who have read "In Northern Spain," published some years ago, will welcome another book of travel by the same author. In the years 1902 and 1904 he spent the long vacation in the south of Mexico in search of zoological specimens, and the present volume not only gives us an entertaining account of the experiences of himself and his wife in localities which are still but little known, but it is a collection of scientific observations and speculations of considerable value, in which, though zoology naturally takes the first place, other branches of research are by no means neglected. He spent a considerable portion of his time in the tierra caliente, the hot tropical lowlands, at a season-from June to September-when vegetable and animal life exhibits the greatest luxuriance and activity. It is, however, a period of excessive heat, and in most places heavy rainfall, so that readers of the book. will obtain an unduly unfavourable impression of life in tropical America. At other times he was at work on the invigorating table-land of Mexico or the slopes of its lofty volcanoes.

Everywhere he was successful in obtaining specimens of new or rare forms of life, and to those who know the difficulties of carrying through a programme where the bridle-path and mule-train are the only means of transport, the amount that he was able to accomplish in the limited time at his disposal will seem marvellous.

The book commences with a description of the environs of the capital, and gives an interesting account of Lake Xochimilco, famous for its floating gardens and the axolotl that inhabits its waters, the questions which arise in connection with the life-history of the latter being discussed in some detail.

The travellers spent some time on Citlaltepetl, el Volcan de Orizaba, where the author was struck by the abrupt character of the upper limits of plants on the mountain-side. "Tillandsia tricolor disappears quite suddenly from the southern slopes at about 9600 feet; the last specimens are just as large and flourishing as those lower down, whilst the conifers upon which they grow, continue without the slightest change. The Pinus liophylla and the Abies religiosa cease at their upper level as very big trees."

The author obtained five species of the land-newt, Spelerpes, one of which, S. variegatus, was ultimately found to extend from an altitude of 9000 feet to the tropical lowlands. He states that "a boxful of $S$. variegatus that he collected in a day's excursion in a tropical region south of Cordoba lived verv well on Citlaltepetl in spite of the low temperature, but those brought from that mountain died within a few days when taken into the tropics; and he considers this to corroborate " the fact that most creatures can endure a temporary change into cooler surroundings, even though they may not flourish under it, while the reverse of such conditions prostrates and kills them." It is, however, doubtful whether this is true of

I "Through Snuthern Mexico. Being an Account of the Travels of a Naturalist." By Hans Gadow, F.R.S. Pp. xvi+527. (London: Witherby and Co., r908.) Price $18 s$. net.

No. 2044, VOL. 79] warm-blooded animals. On the other hand, he contends that there are many more species of animals and plants, which have their " probable centre of origin in temperate climates, and now extend into the tropics and yet remain apparently unaltered, than there are hot country species which have spread into cool climates."

From Orizaba the travellers passed to the low-lying forests of the Rio Tonto, on the northern side of the Isthmus of Tehuantepec, where a goods van shunted on to a siding formed their headquarters. The author's description of a tropical forest is so true to nature that part of it may be quoted here :- " It does not begin gradually. On its outskirts it is fringed by an impenetrable wall of luxuriant herbage, shrubs and creepers. . . It can be entered only by hacking and slashing a path through the tangled growth, which closes up again within a few weeks, except where traffic may have produced a narrow, meandering track, from which it is impossible to deviate either to right or left. Once inside, we are in a

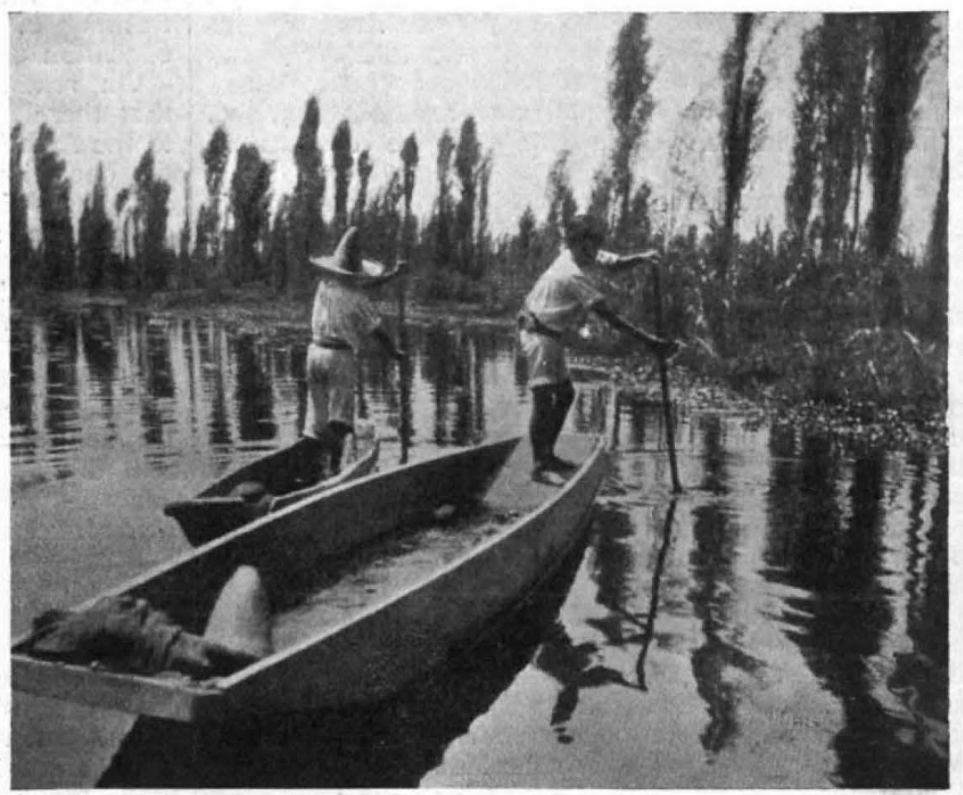

of Lake Xoch:milco. From "Through Southern Mexico."

gloomy, stuffy forest consisting of tall, straight trees, which branch out at a great height above us, there interlacing and forming a dense canopy of green through which passes little or no sunlight. The absence of direct light effectively prevents the growth of underwood, and there are no green, luxuriant plants, no flowers or grass. The ground is brown and black, covered with many inches of rotting leaves and twigs, all turning into a steaming mould. From our point of view below the canopy the leaves, branches, and even bright-coloured birds look black, and this is still more the case where, by contrast, such objects are seen through a rift in the canopy against the glaring sky."

Prof. Gadow describes in detail the adaptation of different groups of animals to forest life, and lays stress on the fact that, given the same conditions, the outward characters of different forms become almost identical. Speaking of the arboreal Anura, he tells us that " the forests have succeeded so well that it is, for in- 
stance, impossible to distinguish certain green treefrogs of the African genus Rappia from a Hyla unless we cut them open. If they lived side by side, which they do not, this close resemblance would be extolled as an example of mimicry. In reality, it is a case of heterogeneous convergence brought about by identical environmental conditions. One might almost say that tropical, moist forests must have tree-frogs, and that these are made out of whatever suitable material happens to be available."

Continuing their journey by rail, the travellers reached Tehuantepec, on the Pacific coast, where the lower rainfall is evidenced by less luxuriant vegetation, and thence travelled on horseback north-westward on to the southern plateau. On the way we learn a great deal about a variety of topics, including "white ants"; Anableps dowei, the "four-eyed" fish; the weaver bird and the method it has devised of suspending its nests from telegraph wires; humming-birds; rattlesnakes, and how they got their rattle, and the exemplary Chontal Indians, who never steal " porque no es costumbre."

In some places the vegetation consists mainly of cacti. After describing the armament of spines that affords them effectual protection, the author reminds us that "cattle and horses, sheep and goats, were all introduced by the Spaniards, and none of the indigenous vegetable-feeders of the plateau, such as stags, squirrels, hares, and mice, can claim to have helped in the evolution of these plants. Are we reduced for an explanation to go back to the extinct fauna? More likely it is one of those cases in which imagination has run away from a more sober and matter-of-fact judgment. It is, no doubt, the case that the conditions prevailing on a high table-land of this kind, subject to prolonged drought, a fierce sun, great and quickly-succeeding changes of temperature, and dust-storms, have produced the characteristics of this family of plants without regard to the animals." We must remember, however, that the Camelidæ and Equidæ must in all probability have formed part of the fauna of Mexico as late as the Pleistocene, as they are found in deposits referred to that period both in North and South America. Some means of defence against these animals would have been absolutely necessary for the preservation of succulent plants in a dry climate where vegetable food was far from plentiful, and it is only reasonable to suppose that the destruction of unprotected forms contributed to the extraordinary development of spines which now characterises the group.

In the second expedition the author and his wife travelled south from the capital by way of Cuernavaca to the terminus of the railway at Balsas. Thence they made their way on horseback over the mountains to a densely wooded portion of the Pacific coast, where they camped on a narrow strip of dry land between a lagoon and the sea. There is a fine description of the nightly thunderstorm which came up from over the sea, a phenomenon of considerable meteorological interest. Unfortunately, in this and many other cases we are not given the date or even the month when the observations recorded were made, though this information would have added considerably to their value.

The illustrations are plentiful and usually clearly reproduced, though one would have wished for more photographs of the phases of animal life which form such an important feature of the text; but with so much compressed into such a brief period it is easy to understand that there was no time for telephotographic work.

NO. 2044, VOL. 79]

\section{THE HEADMASTERS' CONFERENCE.}

$A$ FTER a school career prolonged to the age of eighteen in one of the great public schools, a youth should possess certain minima of endowment -moral, physical and intellectual. His intellectual assets should include a reasonable proficiency in the use of the English language, the ability to read intelligently at least one other language, a notion of what the study of history really means (with some sense of historical perspective), and acquaintance with some fundamental scientific discoveries, together with an inkling of the importance of the advancement of man's control over his environment. He should have an intellectual interest in at least one subject, not necessarily, nor even preferably, included in his school studies. $\Lambda$ charge has been preferred against the schools of failing to equip the majority of the young men who leave their ranks with even this modesi minimum of mental endowment, and the authors of this charge include men whose experience and ability lend weight to their indictment. Interest in the headmasters' debates concerning curricula should not at this juncture be confined to the ranks of the scholastic profession.

There were fifty-two headmasters present at the meetings of the conference, which took place at the Merchant Taylors' School, London, on December 22 and 23. The Rev. Dr. Nairn presided, and the larger schools were well represented. It may be well to remind our readers that by its constitution the conference limits its membership to headmasters of schools where a considerable number of boys remain until the age of eighteen or nineteen. A discussion of the proceedings of the annual congress should throw light on the progress being made towards an improved curriculum.

Special interest attaches to the resolutions relating to the age at which the study of Greek should begin. Two years ago the conference declared that this study should be postponed to the age of thirteen or fourteen, and that Greek should not be a subject of the entrance examination at the schools represented in the conference. Forty-two of the leading schools regulate the admission of boys from the preparatory schools by an examination entitled "Common Examination for Entrance to Public Schools." We find that only five of the forty-two schools have definitely dropped Greek, the remaining thirty-seven disregarding the xoo6 resolution. On the other hand, seventeen schools exclude science, and the remainder make science optional, usually as an alternative to Latin verse. The practical result is that many little boys in preparatory schools are specialising in classics, and their general education is impossible. In other cases we find (to quote Mr. R. C. Gilson, of Birmingham) "the present stupid method of trying to teach three foreign languages together to little boys in knickerbockers." At the age when the observation of nature and education of motor-centres are of special importance, the public schools insist on the pursuit of Latin and Greek to the practical exclusion of manual and observational training. It is hardly to be wondered at that, to quote Mr. Gilson again, " in the name of teaching Greek the schools were turning out men who could not observe nature." This state of affairs will be remedied to some extent if and when practical effect is given to the resolutions of the conference, which affirmed (I) that the average boy cannot undertake the study of more than two languages besides English before the age of thirteen years without detriment to his general education; (2) it is the duty of public schools to provide classes in which the study 